\title{
Studies on Physico-chemical Parameters of Ambawade Reservoir, Raigad District, Maharashtra, India
}

\author{
Snehal S. Lokhande ${ }^{1 *}$, S. T. Indulkar ${ }^{1}$, A. D. Adsul ${ }^{1}$ and Dipesh Kadam ${ }^{1}$ \\ ${ }^{1}$ College of Fisheries, Dr. Balasaheb Sawant Konkan Krishi Vidyapeeth, Dapoli, Shirgaon,
} Ratnagiri - 415 629, India.

Authors' contributions

This work was carried out in collaboration between all authors. All authors read and approved the final manuscript.

Article Information

DOI: $10.9734 / J S R R / 2017 / 33916$

Editor(s):

(1) Prof. Dr. Leszek Labedzki, Institute of Technology and Life Sciences, Kujawsko-Pomorski Research Centre, Poland.

Reviewers:

(1) Marcela Bianchessi da Cunha Santino, Universidade Federal de São Carlos, Brazil.

(2) Fazıl Şen, Yuzuncu Yil University, Turkey.

Complete Peer review History: http://www.sciencedomain.org/review-history/19532

Original Research Article

Received $3^{\text {rd }}$ May 2017

Accepted $17^{\text {th }}$ May 2017

Published 14 ${ }^{\text {th }}$ June 2017

\section{ABSTRACT}

The present study deals with physico-chemical parameters and their correlation coefficient of Ambawade reservoir, Raigad [M.S] India during February 2014 to January 2016. The range of various parameters of reservoirs atmospheric temperature from $25.3^{\circ} \mathrm{C}$ to $36.4^{\circ} \mathrm{C}$, water temperature from 23.5 to $35.7^{\circ} \mathrm{C}$, $\mathrm{pH}$ from 5.80 to 8.40 , DO from 4.56 to $8.32 \mathrm{mg} \mathrm{L}^{-1}$, transparency from 32.56 to $103.40 \mathrm{~cm}$, Free $\mathrm{CO}_{2}$ from nil to $5.90 \mathrm{mg} \mathrm{L}^{-1}$, EC from 58.20 to $110.80 \mu \mathrm{S} \mathrm{cm}^{-1}$, TDS from 8.41 to $18.42 \mathrm{mg} \mathrm{L}^{-1}$, total hardness from 54.40 to $71.32 \mathrm{mg} \mathrm{L}^{-1}$, total alkalinity from 46.32 to $74.21 \mathrm{mg} \mathrm{L}^{-1}, \mathrm{NO}_{3}-\mathrm{N}$ from 0.378 to $1.024 \mathrm{mg} \mathrm{L}^{-1}, \mathrm{PO}_{4}-\mathrm{P}$ from 0.041 to $0.310 \mathrm{mg} \mathrm{L}^{-1}, \mathrm{SiO}_{2}$ from 3.75 to $9.19 \mathrm{mg} \mathrm{L}^{-1}, \mathrm{Mg}^{2+}$ from 5.67 to $8.84 \mathrm{mg} \mathrm{L}^{-1}, \mathrm{Na}^{+}$from 3.04 to $5.66 \mathrm{mg} \mathrm{L}^{-1}$ and $\mathrm{K}^{+}$from 0.36 to $0.98 \mathrm{mg} \mathrm{L}^{-1}$. Correlation coefficient $(r)$ showed high significant positive and negative relationship $(p<0.01$ level) between the parameters. The results revealed that there was a fluctuation in physico-chemical parameters during the period under report.

Keywords: Physico-chemical parameters; seasonal fluctuations. 


\section{INTRODUCTION}

The fresh water bodies were generally aimed to assess the water quality and it's interaction with biotic and abiotic factors [1]. The physicochemical properties of water body influenced by the pattern of nutrients involving both abiotic and biotic components of aquatic ecosystem [2]. The quality of aquatic life depends on the water quality of the respective water body. In order to utilize fresh water bodies for fish production, it is very important to study the physico-chemical factors which influence the biological productivity of the respective water body [1]. The physicchemical characteristics are interrelated to each other and exert influence on the biological communities and biological production of reservoir, for this it is essential to understand the interrelationship. With this the present study was carried out for the monthly observations on physico-chemical parameters of Ambawade reservoir, Raigad [M.S] India during February 2014 to January 2016. The geographical position of Ambawade reservoir is 17-56'43.34" $\mathrm{N}$ and
73⒉'52.27" E and it occupies a total area of 21.7 ha. There are about 817 small reservoirs are located in the Raigad district. However, the reservoirs in the same area within small distance show erratic results in the physico-chemical parameters. It is in this light, the assessment of the water quality parameter is foremost task for the scientific management of Ambawade reservoir and to find out the suitability of the water for multipurpose. Hence the present account is an attempt to accumulate information pertaining to monthly and seasonal variations in various physico-chemical parameters of Ambawade reservoir.

\section{MATERIALS AND METHODS}

The present investigation of physico-chemical parameters of Ambawade reservoir (water area 21.7 ha) was carried out from February-2014 to January-2016. Five sampling stations from reservoir were selected for monthly in-situ water collection.

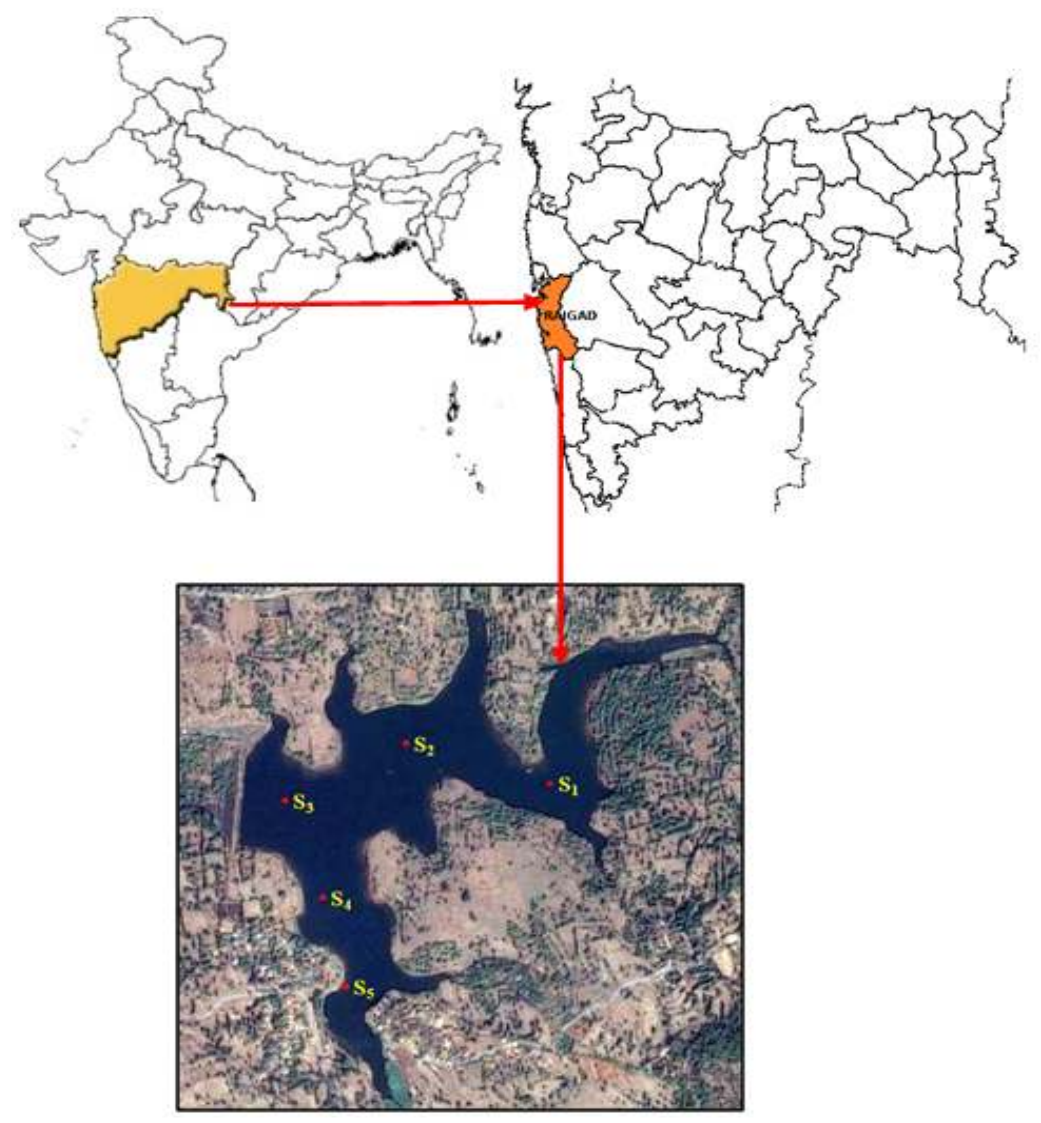

Fig. 1. Sampling stations of Ambawade reservoir 
The water samples were immediately brought to the laboratory for the estimation of various physico-chemical parameters. Atmospheric and water temperatures were recorded by using precision centigrade thermometer with an accuracy of $0.1^{\circ} \mathrm{C}$ and expressed in degree Celsius $\left({ }^{\circ} \mathrm{C}\right) . \mathrm{pH}$ was measured with the help of digital $\mathrm{pH}$ pen having an accuracy of 0.1 , and electrical conductivity $\left(\mu \mathrm{S} \mathrm{cm}{ }^{-1}\right)$ with conductivity meter.

The Water transparency was measured with the help of Secchi disc [3] by the following formula:

$$
\mathrm{SD}(\mathrm{cm})=\frac{A+B}{2}
$$

Where:

$\mathrm{SD}=$ Depth of Sechhi disk visibility in $\mathrm{cm}$

$\mathrm{A}=$ Depth of disappearance of disk in $\mathrm{cm}$

$\mathrm{B}=$ Depth of reappearance of disk in $\mathrm{cm}$

The primary productivity measured with the help of light and dark bottle method [3]. The values for gross photosynthesis, net photosynthesis and community respiration in $\mathrm{mg} \mathrm{L}^{-1}$ of $\mathrm{DO}$ was converted to $\mathrm{mg} \mathrm{L}^{-1}$ of carbon by multiplying the factor 0.375 , the ratio of the weights of carbon to oxygen. The period of incubation for the estimation of primary productivity was three hours.

The other parameters such as dissolved oxygen, free carbon dioxide, total hardness and total alkalinity were estimated by using the standard methods as prescribed [3] by the following formulas:

Dissolved oxygen $\left(\mathrm{mgL}^{-1}\right)=\frac{\mathrm{V} \times \mathrm{N} \times 8 \times 1000}{\mathrm{~S}}$

Where,

$$
\begin{aligned}
& \mathrm{V}=\text { Volume }(\mathrm{ml}) \text { of titrant used }\left(\mathrm{Na}_{2} \mathrm{~S}_{2} \mathrm{O}_{3}\right) \\
& \mathrm{S}=\text { Volume of sample used }\left(\mathrm{ml}^{2}\right) \\
& \mathrm{N}=\text { Normality of titrant used }\left(\mathrm{Na}_{2} \mathrm{~S}_{2} \mathrm{O}_{3}\right) .
\end{aligned}
$$

Free carbon dioxide $\left(\mathrm{mg} \mathrm{L}^{-1}\right)=$

$$
\frac{\left(\mathrm{ml} \text { of } \mathrm{Na}_{2}\right.}{\text { Sample volume in } \mathrm{ml}}
$$

Total hardness $\left(\mathrm{mg} \mathrm{L}^{-1}\right)=$

Volume of EDTA solution used $\times 1000$

$$
\text { Volume of water sample }
$$

Total Alkalinity $\left(\mathrm{mg} \mathrm{L}^{-1}\right)=\frac{\mathrm{T} \times 0.02 \times 50,000}{\mathrm{~V}}$

Where,

$$
\begin{aligned}
& T=\text { Volume of titrant used }\left(\mathrm{H}_{2} \mathrm{SO}_{4}\right) \\
& \mathrm{N}=\text { Normality of standard acid used } \\
& \mathrm{V}=\text { Volume of water sample used }(\mathrm{ml})
\end{aligned}
$$

Following parameters were analyzed by using Spectroquant instrument (Merck) with respective barcodes.

\begin{tabular}{ll}
\hline Parameters & Barcode no. \\
\hline Nitrate $\left(\mathrm{NO}_{3}^{-}-\mathrm{N}\right)$ & 109713 \\
Nitrite $\left(\mathrm{NO}_{2}^{-}-\mathrm{N}\right)$ & 114776 \\
Phosphate $\left(\mathrm{PO}_{4}-\mathrm{P}\right)$ & 14841 \\
Silicate $\left(\mathrm{SiO}_{2}\right)$ & 00857 \\
Iron $\left(\mathrm{Fe}^{2+}\right)$ & 114761 \\
\hline
\end{tabular}

Sodium and potassium were analyzed with the help of flame photometry method [4].

Total dissolved solids and magnesium were analyzed by using standard method [5] by using fallowing formulas:

Total Dissolved Solids $\left(\mathrm{mg} \mathrm{L}^{-1}\right)$ :

$$
\frac{(A-B) \times 1000}{\text { Volume of sample }(\mathrm{ml})}
$$

Where,

$A=$ Final weight of dish (with sample)

$\mathrm{B}=$ Initial weight of dish (without sample)

Magnesium $\left(\mathrm{mg} \mathrm{L}^{-1}\right)$ :

$(A-B) \times 400.8 \times 1.645$

$\mathrm{ml}$ of sample taken

Where,

$$
A=\text { EDTA used in hardness determination }
$$$$
B=\text { EDTA used in calcium determination }
$$

The analysis of data was carried out by taking average of five sampling stations of reservoir. The Pearson Correlation Coefficient (r) was carried out between the physicochemical parameters by SPSS (version 16.0 SPSS Inc.). 


\section{RESULTS AND DISCUSSION}

\subsection{Atmospheric and Water Temperatures}

Temperature is basically important parameters and affects on the chemical and biological parameters of water [6]. During investigation of two years, atmospheric temperature of Ambawade reservoir varied from 25.3 to $36.4^{\circ} \mathrm{C}$ with an average of $30.3 \pm 0.7^{\circ} \mathrm{C}$ and water temperature from 23.5 to $35.7^{\circ} \mathrm{C}$ with an average of $28.6 \pm 3.4^{\circ} \mathrm{C}$. It was noticed that water temperature was always lower than that of atmospheric temperature. The atmospheric temperature was observed minimum $\left(27.0^{\circ} \mathrm{C}\right)$ during monsoon season 2015-16 and maximum $\left(34.1^{\circ} \mathrm{C}\right)$ during pre-monsoon season 2014-15. However, the lowest $\left(25.6^{\circ} \mathrm{C}\right)$ of water temperature was recorded during monsoon 2015-16 and the highest $\left(32.4^{\circ} \mathrm{C}\right)$ during premonsoon 2015-16. During the present observations, correlation coefficient reveled that, as atmospheric temperature increases then there was increase in water temperature, free $\mathrm{CO}_{2}$, $\mathrm{EC}, \mathrm{Mg}^{2+}, \mathrm{Na}^{+}$and $\mathrm{SiO}_{2}$ concentration whereas, negative correlation with the $\mathrm{NO}_{3}{ }^{-}-\mathrm{N}$ and $\mathrm{DO}$. Water temperature showed positive correlation with $\mathrm{pH}$, free $\mathrm{CO}_{2}, \mathrm{EC}, \mathrm{Mg}^{2+}, \mathrm{Na}^{+}$and $\mathrm{SiO}_{2}$, whereas negative correlation with the $\mathrm{NO}_{3}{ }^{-}-\mathrm{N}$ and DO. From Barna reservoir, recorded atmospheric temperature ranged from 24 to $39.7^{\circ} \mathrm{C}$, with an average of $31.5 \pm 5.3^{\circ} \mathrm{C}$; however water temperature ranged between 21.3 to $32.3^{\circ} \mathrm{C}$, with mean average of $26.0 \pm 3.9^{\circ} \mathrm{C}$ [7]. During the investigation of water quality parameters of Wyra reservoir, Telangana observed atmospheric temperature ranged from 22.8 to $33.7^{\circ} \mathrm{C}$ and water temperature from 21.6 to $30.9^{\circ} \mathrm{C}$ in different seasons. They also noticed that water temperature was always lower than that of atmospheric temperature [8].

\section{$3.2 \mathrm{pH}$}

The $\mathrm{pH}$ varied in the range of 5.80 to 8.40 with an average of $6.76 \pm 0.70$. Seasonally, the minimum (6.20) value of $\mathrm{pH}$ was recorded during post-monsoon 2014-15 and the maximum (7.45) during pre-monsoon 2014-15. The correlation coefficient analysis indicated that $\mathrm{pH}$ had positive correlation with free $\mathrm{CO}_{2}, \mathrm{EC}, \mathrm{Mg}^{2+}, \mathrm{Na}^{+}, \mathrm{K}^{+}$and $\mathrm{SiO}_{2}$, whereas it showed negative correlation with DO. Similar observations on $\mathrm{pH}$ were reported from Harsool-Savangi dam of Aurangabad and from Khanapur reservoir in Kolhapur district [9] and [10]. They have observed $\mathrm{pH}$ range between 7.9 to 8.6 and 6.4 to 8.64 respectively.

\subsection{Dissolved Oxygen}

It is one of the most important parameters in water is of great limnological significance. The DO content of reservoir varied in the range of 4.56 to $8.32 \mathrm{mg} \mathrm{L}^{-1}$ with an average of $6.72 \pm$ $1.03 \mathrm{mg} \mathrm{L}^{-1}$. Among the season, lowest value (5.48 $\mathrm{mg} \mathrm{L}^{-1}$ ) of DO was recorded during premonsoon2014-15, while highest $\left(7.87 \mathrm{mg} \mathrm{L}^{-1}\right)$ during post-monsoon2015-16. Lower DO in premonsoon may be due to high temperature and low solubility of oxygen in water while maximum DO during post-monsoon might be due to low atmospheric temperature and intensive photosynthetic activity. Correlation coefficient analysis showed that the $\mathrm{DO}$ negative correlation with free $\mathrm{CO}_{2}, \mathrm{EC}$ and $\mathrm{Mg}^{2+}$. In Harsool-Savangi dam, recorded $D O$ values ranged from $4 \mathrm{mg} \mathrm{L}^{-1}$ to $6.9 \mathrm{mg} \mathrm{L}^{-1}$ with an average of $5.46 \pm 0.8 \mathrm{mg}$ $\mathrm{L}^{-1}$. The maximum value $\left(6.3 \pm 0.43 \mathrm{mg} \mathrm{L}^{-1}\right)$ of DO was observed in post-monsoon and minimum $\left(4.7 \pm 0.38 \mathrm{mg} \mathrm{L}^{-1}\right)$ in pre-monsoon [9].

\subsection{Transparency}

The transparency of natural waters is an indicator of productivity. In the investigation period, it ranged from 32.56 to $103.40 \mathrm{~cm}$ with an average of $72.15 \pm 18.70 \mathrm{~cm}$. According to season, the lowest $(38.50 \mathrm{~cm})$ transparency was recorded during monsoon 2014-15 and highest $(89.60 \mathrm{~cm})$ during post-monsoon 2015-16. Low values of transparency in monsoon may be due to influx of rain water from catchments area, cloudiness, less penetration of light and high turbidity due to suspended inert particulate matter. However, high values of transparency in post-monsoon because of suspended matter get settled and deposited in the bottom. Transparency of water showed a negative correlation with total hardness and total alkalinity. The reported transparency values of Ramsagar reservoir (M.P) ranged from 66.59 to $116.00 \mathrm{~cm}$ [11] and in Tighra reservoir it ranged from 91.75 to $165.63 \mathrm{~cm}$ [12]. During the study of Pillowa Reservoir, the recorded higher transparency values ranged from 73.75 to $399.50 \mathrm{~cm}$ with an average of $171.08 \pm 14.40 \mathrm{~cm}$ [13]. The lower values of transparency during monsoon and higher value during post-monsoon were also recorded by above mention researchers $[11,12$, 13].

\subsection{Free Carbon Dioxide (free $\mathrm{CO}_{2}$ )}

The carbon dioxide content of water depends upon the water temperature, depth, rate of 
respiration, decomposition of organic matter, chemical nature of the bottom and geographical features of the terrain surrounding the water body [14]. It ranged from nil to $5.90 \mathrm{mg} \mathrm{L}^{-1}$ with an average of $2.25 \pm 1.57 \mathrm{mg} \mathrm{l}^{-1}$. Seasonally, during post-monsoon $2015-16$ the lowest $(0.45$ $\mathrm{mg} \mathrm{L}^{-1}$ ) content of $\mathrm{CO}_{2}$ was recorded, while highest $\left(4.17 \mathrm{mg} \mathrm{L}^{-1}\right)$ during pre-monsoon 2015 16. It showed positive correlation with TDS and EC. In Savitri reservoir of Raigad district, observed free $\mathrm{CO}_{2}$ ranged between nil to 8.93 $\mathrm{mg} \mathrm{L}^{-1}$ [15]. Similarly, from Govindgarh lake and Harsi reservoir of M.P. observed free $\mathrm{CO}_{2}$ concentration ranged from 1.98 to $9.68 \mathrm{mg} \mathrm{L}^{-1}$ and nil to $2.76 \mathrm{mg} \mathrm{L}^{-1}$ [16] and [17].

\subsection{Electrical Conductivity (EC)}

The electrical conductivity is referred as key factor for determining the purity of water that depends on nature and concentration of ionized substances in the water and water temperature [7]. In the study period, EC content ranged from 58.20 to $110.80 \mu \mathrm{S} \mathrm{cm}{ }^{-1}$ with an average of $79.77 \pm 14.66 \mu \mathrm{S} \mathrm{cm} \mathrm{cm}^{-1}$. Seasonally, during monsoon 2014-15 and pre-monsoon 2015-16, the lowest $\left(66.10 \mu \mathrm{S} \mathrm{cm}^{-1}\right)$ and highest $(94.25 \mu \mathrm{S}$ $\mathrm{cm}^{-1}$ ) content of EC were recorded. The increased in the concentration of $\mathrm{Mg}^{2+}, \mathrm{Na}^{+}$and $\mathrm{SiO}_{2}$ showed that EC is also increased during pre-monsoon season. In Pillowa reservoir, observed EC values ranged from $89.04 \mu \mathrm{S} \mathrm{m}^{-1}$ to $291.20 \mu \mathrm{S} \mathrm{cm}^{-1}$ with an average of $196.0 \pm$ $9.39 \mu \mathrm{S} \mathrm{cm}^{-1}$. They recorded higher values of $E C$ during the pre-monsoon in comparison to rainy and post-monsoon season [13].

\subsection{Total Dissolved Solids (TDS)}

Solids refer to suspended and dissolved matter in water. The TDS content varied from 8.41 to 18.42 with an average of $12.86 \pm 2.79$. Among the seasons, the lowest $\left(9.55 \mathrm{mg} \mathrm{L}^{-1}\right)$ and highest $\left(15.93 \mathrm{mg} \mathrm{L}^{-1}\right)$ content of TDS were recorded during the post-monsoon 2014-15 and pre-monsoon 2014-15. TDS was positively correlated total hardness and total alkalinity. Present investigation trend was in agreement with the finding of other researchers $[7,8]$.

\subsection{Total Hardness}

The total hardness is not a specific constituent of water but is a variable and complex mixture of cations and anions and is predominantly contributed by calcium and magnesium [2]. In the investigation period, it varied from 54.40 to 71.32 $\mathrm{mg} \mathrm{L}^{-1}$ with an average of $63.42 \pm 4.78 \mathrm{mg} \mathrm{L}^{-1}$. Seasonally, the minimum $\left(56.46 \mathrm{mg} \mathrm{l}^{-1}\right)$ and maximum ( $67.28 \mathrm{mg} \mathrm{L}^{-1}$ ) of hardness were recorded during post-monsoon 2014-15 and monsoon 2014-15. These high values may be due to the addition of calcium and magnesium salts. Monthly variations in total hardness were also reported from Pillowa reservoir from 62.00 $\mathrm{mg} \mathrm{L}^{-1}$ to $115.50 \mathrm{mg} \mathrm{L}^{-1}$ and from Harsi reservoir with a range of 63.0 to $103.0 \mathrm{mg} \mathrm{L}^{-1}$ [13] and [17]. During the study of Savitri reservoir, recorded hardness values range from 36.67 to $62.67 \mathrm{mg} \mathrm{L}^{-1}$ [15]. With respect to the Ramsagar reservoir, it falls under the category of soft water body with hardness ranging from 34.00 to 75.25 $\mathrm{mg} \mathrm{L}^{-1}$ [11]. During investigation, Hardness had positive correlation with alkalinity, $\mathrm{NO}_{3}{ }^{-} \mathrm{N}$ and $\mathrm{PO}_{4}-\mathrm{P}$. However, positive correlation of hardness with the alkalinity and $\mathrm{PO}_{4}-\mathrm{P}$ was also reported from Savitri reservoir [15].

\subsection{Total Alkalinity}

Alkalinity is a measure of buffering capacity of the water [2]. It varied from 46.32 to $74.21 \mathrm{mg} \mathrm{L}^{-1}$ with an average of $59.48 \pm 17.24 \mathrm{mg} \mathrm{L}^{-1}$. Seasonally, during post-monsoon 2014-15 the lowest (50.97 $\mathrm{mg} \mathrm{L}^{-1}$ ) and during monsoon 201415 the highest $\left(67.80 \mathrm{mg} \mathrm{L}^{-1}\right)$ of total alkalinity was observed. Total alkalinity was recorded minimum during post-monsoon and maximum during monsoon was also reported in Tighra reservoir [12]. During investigation positive correlation was recorded between alkalinity and $\mathrm{NO}_{3}{ }^{-}-\mathrm{N}$. Similar correlation was also recorded in Hirahalla reservoir, Karnataka [18]. The alkalinity recorded from Savitri reservoir ranged from 34 to $76.66 \mathrm{mg} \mathrm{L}^{-1}$ [15]. In Harsi reservoir, the minimum $\left(30.50 \mathrm{mg} \mathrm{L}^{-1}\right)$ average value of alkalinity was reported in the month of February, while maximum average value of $\left(76.22 \mathrm{mg} \mathrm{L}^{-1}\right)$ reported in the month of June [17]. On the basis of reservoir productivity an overall range of alkalinity ranged from 40 to $240 \mathrm{mg} \mathrm{L}^{-1}$, with $<40$ (low productive), 40 to 90 (medium productive) and $>90$ (high productive) [19]. As this alkalinity classification is applied to Ambawade reservoir it showed a medium productive nature.

\subsection{Nitrate $\left(\mathrm{NO}_{3}^{-}-\mathrm{N}\right)$}

Nitrate $\left(\mathrm{NO}_{3}{ }^{-} \mathrm{N}\right)$ is one of the most important nutrient which accounts for the productivity in water. It ranged from 0.378 to $1.024 \mathrm{mg} \mathrm{L}^{-1}$, with an average of $0.751 \pm 0.17 \mathrm{mg} \mathrm{L}^{-1}$. Seasonally, during pre-monsoon 2014-15 and monsoon 2015-2016, the lowest $\left(0.503 \mathrm{mg} \mathrm{L}^{-1}\right)$ and highest 
(0.950 mg L') concentration of $\mathrm{NO}_{3}{ }^{-}-\mathrm{N}$ were recorded. $\mathrm{NO}_{3}-\mathrm{N}$ content was recorded high during monsoon might be due to influx nitrogen rich water that brings about large amount of contaminated sewage water, leaching of nitrate bearing rocks and decaying macrophytes. During the study of Tighra reservoir, reported $\mathrm{NO}_{3}{ }^{-} \mathrm{N}$ concentration ranged from 0.019 and $0.048 \mathrm{mg}$ $\mathrm{L}^{-1}$, with a mean of $0.032 \pm 0.0017 \mathrm{mg} \mathrm{L}^{-1}$ [12]. In Savitri reservoir, it observed from 0.058 to 0.315 $\mathrm{mg} \mathrm{L}^{-1}$ [15]. The classified nitrate concentration on the basis of productivity for the Indian reservoirs i.e low (negligible), medium (up to 0.2 $\left.\mathrm{mg} \mathrm{L}^{-1}\right)$ and high productive $\left(0.2\right.$ to $\left.0.5 \mathrm{mg} \mathrm{L}^{-1}\right)$ [19]. According to this classification the reservoir of present investigation had shown medium to high productive nature.

Table. 1. Range of variation and mean with standard deviation of physico-chemical characteristics of Ambawade reservoir (Feb. 2014 - Jan. 2016)

\begin{tabular}{|c|c|c|}
\hline Parameters & Range & $\begin{array}{l}\text { Yearly } \\
\text { average }\end{array}$ \\
\hline Atm.Temp. ('C) & $25.3-36.4$ & $30.3 \pm 3.2$ \\
\hline Water.Temp. $\left({ }^{\circ} \mathrm{C}\right)$ & $23.5-35.7$ & $28.6 \pm 3.4$ \\
\hline $\mathrm{pH}$ & $5.8-8.4$ & $6.76 \pm 0.70$ \\
\hline $\mathrm{DO}\left(\mathrm{mg} \mathrm{L}^{-1}\right)$ & $4.56-8.32$ & $6.72 \pm 1.03$ \\
\hline Free $\mathrm{CO}_{2}\left(\mathrm{mg} \mathrm{L}^{-1}\right)$ & $0-5.9$ & $2.25 \pm 1.57$ \\
\hline $\mathrm{EC}\left(\mu \mathrm{S} \mathrm{cm}{ }^{-1}\right)$ & $58.2-110.8$ & $79.77 \pm 14.66$ \\
\hline Trans. (cm) & $32.56-103.4$ & $72.15 \pm 18.7$ \\
\hline TDS $\left(\mathrm{mg} \mathrm{L}^{-1}\right)$ & $8.41-18.42$ & $12.86 \pm 2.79$ \\
\hline Tot. hard. $\left(\mathrm{mg} \mathrm{L}^{-1}\right)$ & $54.4-71.32$ & $63.42 \pm 4.78$ \\
\hline Tot. alkal. (mg L $\left.{ }^{-1}\right)$ & $46.32-74.21$ & $59.48 \pm 7.24$ \\
\hline $\mathrm{NO}_{3}^{-}-\mathrm{N}\left(\mathrm{mg} \mathrm{L}^{-1}\right)$ & $0.378-1.024$ & $0.751 \pm 0.17$ \\
\hline $\mathrm{PO}_{4}-\mathrm{P}\left(\mathrm{mg} \mathrm{L}^{-1}\right)$ & $0.041-0.31$ & $0.100 \pm 0.07$ \\
\hline $\mathrm{SiO}_{2}\left(\mathrm{mg} \mathrm{L}^{-1}\right.$ & $3.75-9.19$ & $6.85 \pm 1.73$ \\
\hline $\mathrm{Mg}^{2+}\left(\mathrm{mg} \mathrm{L}^{-1}\right)$ & $5.67-8.84$ & $6.97 \pm 0.82$ \\
\hline $\mathrm{Na}^{+}\left(\mathrm{mg} \mathrm{L}^{-1}\right)$ & $3.04-5.66$ & $4.51 \pm 0.72$ \\
\hline $\mathrm{K}^{+}\left(\mathrm{mg} \mathrm{L}^{-1}\right)$ & $0.36-0.98$ & $0.71 \pm 0.16$ \\
\hline
\end{tabular}

\subsection{Phosphate $\left(\mathrm{PO}_{4}-\mathrm{P}\right)$}

Phosphorus, necessary for the fertility and it generally recognized as a key nutrient in the productivity of the water [2]. $\mathrm{PO}_{4}-\mathrm{P}$ concentration varied from 0.041 to $0.310 \mathrm{mg} \mathrm{L}^{-1}$ with an average of $0.100 \pm 0.07 \mathrm{mg} \mathrm{L}^{-1}$. The lowest $\left(0.057 \mathrm{mg} \mathrm{L}^{-1}\right)$ concentration of $\mathrm{PO}_{4}-\mathrm{P}$ was observed during post-monsoon season 2014-15 and highest $\left(0.232 \mathrm{mg} \mathrm{L}^{-1}\right)$ concentration during monsoon 2015-16. The higher $\mathrm{PO}_{4}-\mathrm{P}$ values observed during monsoon season could be attributed influx through rain water and surface run off. From Govindgarh lake, the phosphate concentartion recorded from 25 to $3.35 \mathrm{mg} \mathrm{L}^{-1}$ [16]. During the investigation of Ramsagar reservoir, observed $\mathrm{PO}_{4}-\mathrm{P}$ in the range of 0.013 to $0.054 \mathrm{mg} \mathrm{L}^{-1}$ [11]. However, from Tighra reservoir, observed $\mathrm{PO}_{4}-\mathrm{P}$ values from 0.37 to $1.57 \mathrm{mg} \mathrm{L}^{-1}$ [20]. The $\mathrm{PO}_{4}-\mathrm{P}$ content more than $0.2 \mathrm{mg} \mathrm{L}^{-1}$ are likely to be quite productive [21]. While, on the basis of $\mathrm{PO}_{4}-\mathrm{P}$ content in water bodies has been classified into three categories, low (negaligible), medium (up to $0.1 \mathrm{mg} \mathrm{L}^{-1}$ ) and high $\left(0.1\right.$ to $\left.0.2 \mathrm{mg} \mathrm{L}^{-1}\right)$ [19]. When the classification is applied to $\mathrm{PO}_{4}-\mathrm{P}$ content in water of the reservoir, this can be placed under medium to high productive water body.

\subsection{Silicate $\left(\mathrm{SiO}_{2}\right)$}

Silicate is most abundant in sedimentary rocks. The ranged from 3.75 to $9.19 \mathrm{mg} \mathrm{L}^{-1}$ with an average of $6.85 \pm 1.73 \mathrm{mg} \mathrm{L}^{-1}$. Seasonally, during post-monsoon 2014-15 lowest $\left(5.07 \mathrm{mg} \mathrm{L}^{-1}\right) \mathrm{SiO}_{2}$ content was recorded and highest $\left(8.61 \mathrm{mg} \mathrm{L}^{-1}\right)$ during pre-monsoon 2014-2015. Lowest concentration of $\mathrm{SiO}_{2}$ during the post-monsoon season found to be related with their continuous utilization by phytoplankton and lower temperature can also helps in low decomposition activity. From Ramsagar reservoir, observed silicate concentration ranged from 0.65 to 8.42 $\mathrm{mg} \mathrm{L}^{-1}[11]$ and from Savitri reservoir, it ranged from 8.59-23.06 $\mathrm{mg} \mathrm{L}^{-1}[15]$.

\subsection{Magnesium $\left(\mathrm{Mg}^{2+}\right)$}

Magnesium is often associated with calcium in all kinds of waters, but its concentration remains generally lower than the calcium [22]. $\mathrm{Mg}^{2+}$ concentration ranged from 5.67 to $8.84 \mathrm{mg} \mathrm{L}^{-1}$ with an average of $6.97 \pm 0.82 \mathrm{mg} \mathrm{L}^{-1}$. According to seasons, the lowest $\left(6.47 \mathrm{mg} \mathrm{L}^{-1}\right)$ and highest $\left(8.10 \mathrm{mg} \mathrm{L}^{-1}\right)$ concentration of $\mathrm{Mg}^{2+}$ were recorded during the monsoon 2015-16 and during pre-monsoon2014-15. It showed positive correlation with the $\mathrm{Na}^{+}, \mathrm{K}^{+}$and $\mathrm{SiO}_{2}$, while negative correlation only with $\mathrm{NO}_{3}{ }^{-}-\mathrm{N}$. In Tighra reservoir, observed concentration of magnesium ranged from 2.47 to $5.13 \mathrm{mg} \mathrm{L}^{-1}$ with a mean value of $3.58 \pm 0.16$ [12]. In Harsi reservoir, magnesium was recorded from $3.02-7.87 \mathrm{mg} \mathrm{L}^{-1}$ [17]. However, from the Mahagaon reservoir, the reported magnesium content ranged from 15.25 to $25.99 \mathrm{mg} \mathrm{L}^{-1}$ with an average of $21.09 \mathrm{mg}$ $\mathrm{L}^{-1}[23]$. 
Lokhande et al.; JSRR, 14(5): 1-10, 2017; Article no.JSRR.33916

Table 2. Seasonal variation of physico-chemical characteristics of Ambawade reservoir from Feb.2014 - Jan. 2016

\begin{tabular}{|c|c|c|c|c|c|c|}
\hline \multirow[t]{3}{*}{ Parameters } & \multicolumn{3}{|c|}{ Feb. 14 - Jan. 15} & \multicolumn{3}{|c|}{ Feb. 15 - Jan. 16} \\
\hline & Pre-monsoon & Monsoon & Post-monsoon & Pre-monsoon & Monsoon & Post-monsoon \\
\hline & Feb & Sept & Jan & May & Sept & Jan \\
\hline A.T. $\left({ }^{\circ} \mathrm{C}\right)$ & $34.1 \pm 1.3$ & $29.3 \pm 3.8$ & $29.7 \pm 1.0$ & $33.0 \pm 3.5$ & $27.0 \pm 1.2$ & $28.8 \pm 2.0$ \\
\hline W.T. ('C) & $31.8 \pm 1.7$ & $26.7 \pm 3.6$ & $27.8 \pm 1.6$ & $32.4 \pm 3.2$ & $25.6 \pm 1.6$ & $27.1 \pm 1.7$ \\
\hline $\mathrm{pH}$ & $7.45 \pm 0.7$ & $6.20 \pm 0.7$ & $6.20 \pm 0.2$ & $7.10 \pm 0.7$ & $6.45 \pm 0.7$ & $6.35 \pm 0.3$ \\
\hline $\mathrm{DO}\left(\mathrm{mg} \mathrm{L}^{-1}\right)$ & $5.48 \pm 0.7$ & $6.68 \pm 0.7$ & $6.88 \pm 0.3$ & $5.94 \pm 1.0$ & $7.47 \pm 0.6$ & $7.87 \pm 0.5$ \\
\hline Free $\mathrm{CO}_{2}\left(\mathrm{mg} \mathrm{L}^{-1}\right)$ & $3.52 \pm 1.1$ & $2.19 \pm 0.9$ & $1.40 \pm 0.5$ & $4.17 \pm 1.7$ & $1.98 \pm 0.9$ & $0.45 \pm 0.5$ \\
\hline $\mathrm{EC}\left(\mu \mathrm{S} \mathrm{cm} \mathrm{cm}^{-1}\right)$ & $90.18 \pm 8.97$ & $66.10 \pm 13.30$ & $66.60 \pm 6.20$ & $94.25 \pm 15.75$ & $82.85 \pm 10.36$ & $78.65 \pm 8.88$ \\
\hline Trans. (cm) & $71.1 \pm 2.5$ & $38.5 \pm 6.8$ & $81.9 \pm 10.5$ & $85.1 \pm 3.8$ & $66.7 \pm 7.3$ & $89.6 \pm 12.2$ \\
\hline TDS (mg L $\left.{ }^{-1}\right)$ & $15.93 \pm 2.15$ & $12.76 \pm 2.40$ & $9.55 \pm 1.35$ & $13.50 \pm 1.95$ & $13.70 \pm 2.84$ & $11.70 \pm 2.27$ \\
\hline Tot. hard. $\left(\mathrm{mg} \mathrm{L}^{-1}\right)$ & $62.44 \pm 4.1$ & $67.28 \pm 3.4$ & $56.46 \pm 2.6$ & $65.05 \pm 3.5$ & $66.91 \pm 4.4$ & $62.37 \pm 1.2$ \\
\hline Tot. alkal. $\left(\mathrm{mg} \mathrm{L}^{-1}\right)$ & $56.85 \pm 2.7$ & $67.80 \pm 4.9$ & $50.97 \pm 4.3$ & $58.90 \pm 7.9$ & $66.23 \pm 2.7$ & $56.16 \pm 2.9$ \\
\hline $\mathrm{NO}_{3}^{-}-\mathrm{N}\left(\mathrm{mg} \mathrm{L}^{-1}\right)$ & $0.503 \pm 0.12$ & $0.850 \pm 0.08$ & $0.687 \pm 0.08$ & $0.685 \pm 0.12$ & $0.950 \pm 0.06$ & $0.834 \pm 0.11$ \\
\hline $\mathrm{PO}_{4}-\mathrm{P}\left(\mathrm{mg} \mathrm{L}^{-1}\right)$ & $0.066 \pm 0.006$ & $0.083 \pm 0.01$ & $0.057 \pm 0.02$ & $0.071 \pm 0.014$ & $0.232 \pm 0.09$ & $0.090 \pm 0.06$ \\
\hline $\mathrm{SiO}_{2}\left(\mathrm{mg} \mathrm{L}^{-1}\right)$ & $8.61 \pm 0.4$ & $6.32 \pm 2.6$ & $5.07 \pm 1.3$ & $7.03 \pm 0.6$ & $5.96 \pm 0.8$ & $8.09 \pm 1.2$ \\
\hline $\mathrm{Mg}^{2+}\left(\mathrm{mg} \mathrm{L}^{-1}\right)$ & $8.10 \pm 0.6$ & $6.88 \pm 1.2$ & $6.65 \pm 0.6$ & $6.75 \pm 0.4$ & $6.47 \pm 0.6$ & $7.00 \pm 0.4$ \\
\hline $\mathrm{Na}^{+}\left(\mathrm{mg} \mathrm{L}^{-1}\right)^{\prime}$ & $5.06 \pm 0.2$ & $3.87 \pm 0.7$ & $3.68 \pm 0.5$ & $5.33 \pm 0.3$ & $4.30 \pm 0.2$ & $4.82 \pm 0.3$ \\
\hline $\mathrm{K}^{+}\left(\mathrm{mg} \mathrm{L}^{-1}\right)$ & $0.87 \pm 0.09$ & $0.71 \pm 0.08$ & $0.54 \pm 0.15$ & $0.72 \pm 0.08$ & $0.56 \pm 0.12$ & $0.83 \pm 0.08$ \\
\hline
\end{tabular}


Table 3. Correlation coefficient between physico-chemical parameters from Feb. 2014 - Jan. 2016

\begin{tabular}{|c|c|c|c|c|c|c|c|c|c|c|c|c|c|c|c|c|}
\hline & A. $\mathrm{T}$. & W. T. & $\mathbf{p H}$ & Trans. & DO & Free $\mathrm{CO}_{2}$ & TDS & $\begin{array}{l}\text { Tot. } \\
\text { hard. }\end{array}$ & Tot. alkal & EC & $\mathrm{Mg}^{2+}$ & $\mathrm{Na}^{+}$ & $\mathrm{K}^{+}$ & $\mathrm{SiO}_{2}$ & $\mathrm{NO}_{3}{ }^{-}-\mathrm{N}$ & $\mathrm{PO}_{4}-\mathrm{P}$ \\
\hline A. $T$. & 1 & & & & & & & & & & & & & & & \\
\hline W. T. & $.969^{* *}$ & 1 & & & & & & & & & & & & & & \\
\hline $\mathrm{pH}$ & $.710^{* *}$ & $.669^{\star *}$ & 1 & & & & & & & & & & & & & \\
\hline Trans. & 0.238 & 0.33 & -0.131 & 1 & & & & & & & & & & & & \\
\hline DO & $-.862^{\star *}$ & $-.831^{\star *}$ & $-.748^{* *}$ & -0.005 & 1 & & & & & & & & & & & \\
\hline Free $\mathrm{CO}_{2}$ & $.572^{\star \star}$ & $.625^{\star *}$ & $.653^{\star *}$ & -0.094 & $-.685^{\star \star}$ & 1 & & & & & & & & & & \\
\hline TDS & 0.142 & 0.154 & 0.392 & -0.333 & -0.304 & $.543^{\star \star}$ & 1 & & & & & & & & & \\
\hline Tot. hard & -0.078 & -0.053 & 0.26 & $-.516^{\star \star}$ & -0.03 & 0.352 & $.620^{* *}$ & 1 & & & & & & & & \\
\hline Tot. Alka. & -0.211 & -0.238 & 0.285 & $-.711^{\star \star}$ & -0.015 & 0.284 & $.522^{* *}$ & $.748^{\star *}$ & 1 & & & & & & & \\
\hline EC & $.671^{\star *}$ & $.722^{\star *}$ & $.693^{\star \star}$ & $.429^{\star}$ & $-.594^{\star *}$ & $.566^{\star *}$ & 0.3 & 0.191 & 0.041 & 1 & & & & & & \\
\hline $\mathrm{Mg}^{2+}$ & $.697^{* *}$ & $.624^{* *}$ & $.739^{\star *}$ & 0.165 & $-.607^{\star *}$ & 0.198 & 0.077 & -0.173 & -0.2 & $.588^{\star *}$ & 1 & & & & & \\
\hline $\mathrm{Na}^{+}$ & $.621^{\star *}$ & $.670^{\star *}$ & $.575^{\star \star}$ & $.508^{\star}$ & $-.459^{\star}$ & 0.392 & 0.282 & 0.084 & -0.123 & $.863^{\star \star}$ & $.615^{\star \star}$ & 1 & & & & \\
\hline $\mathrm{K}^{+}$ & $.499^{*}$ & $.481^{*}$ & $.525^{\star *}$ & 0.204 & $-.441^{*}$ & 0.218 & 0.323 & 0.056 & -0.019 & $.513^{\star}$ & $.663^{* *}$ & $.671^{\star *}$ & 1 & & & \\
\hline $\mathrm{SiO}_{2}$ & $.582^{\star \star}$ & $.532^{\star *}$ & $.583^{\star *}$ & 0.324 & -0.398 & 0.097 & 0.121 & -0.066 & -0.148 & $.640^{\star *}$ & $.839^{\star *}$ & $.826^{\star *}$ & $.804^{* *}$ & 1 & & \\
\hline $\mathrm{NO}_{3}^{-}-\mathrm{N}$ & $-.616^{\star *}$ & $-.588^{* *}$ & -0.249 & -0.359 & $.574^{\star \star}$ & -0.231 & 0.071 & $.555^{\star \star}$ & $.643^{\star *}$ & -0.239 & $-.516^{\star \star}$ & -0.379 & -0.358 & $-.423^{*}$ & 1 & \\
\hline $\mathrm{PO}_{4}-\mathrm{P}$ & $-.496^{\star}$ & $-.468^{*}$ & -0.286 & -0.288 & $.448^{*}$ & -0.2 & 0.329 & $.537^{\star *}$ & $.458^{\star}$ & -0.067 & -0.375 & -0.172 & $-.444^{*}$ & -0.309 & $.655^{\star *}$ & 1 \\
\hline
\end{tabular}




\subsection{Sodium $\left(\mathrm{Na}^{+}\right)$}

The concentration of sodium in freshwater is generally lower than calcium and magnesium [6]. $\mathrm{Na}^{+}$content ranged from 3.04 to $5.66 \mathrm{mg} \mathrm{L}^{-1}$ with an average of $4.51 \pm 0.72 \mathrm{mg} \mathrm{L}^{-1}$. Among the seasons, during post-monsoon 2014-15, the lowest (3.68 $\mathrm{mg} \mathrm{L}^{-1}$ ) and during pre-monsoon 2015-16, the highest $\left(5.33 \mathrm{mg} \mathrm{L}^{-1}\right)$ concentration of $\mathrm{Na}^{+}$was observed. The lower value of $\mathrm{Na}^{+}$ recorded during post-monsoon season was may be due to utilization by plankton and other aquatic organisms, while higher value during premonsoon due to evaporation of water. $\mathrm{Na}^{+}$ showed positive correlation with $\mathrm{K}^{+}$and $\mathrm{SiO}_{2}$. Similar trend of $\mathrm{Na}^{+}$values was also reported from the Khanapur reservoir, with values ranged from 7 to $12 \mathrm{mg} \mathrm{L}^{-1}$ [10]. From Tighra reservoir, the concentration of sodium reported with an average of $4.22 \pm 0.15 \mathrm{mg} \mathrm{L}^{-1}$ while, from Harsi reservoir, it ranged from 10.02 to $20.79 \mathrm{mg} \mathrm{L}^{-1}$ $[12,17]$.

\subsection{Potassium $\left(\mathrm{K}^{+}\right)$}

Potassium $\left(\mathrm{K}^{+}\right)$is naturally occurring element which remains far lesser in concentration that calcium, magnesium and sodium in freshwaters [2]. The $\mathrm{K}^{+}$concentration varied from 0.36 to 0.98 $\mathrm{mg} \mathrm{L}^{-1}$ with an average of $0.71 \pm 0.16 \mathrm{mg} \mathrm{L}^{-1}$. Seasonally, the minimum $\left(0.54 \mathrm{mg} \mathrm{L}^{-1}\right)$ content of $\mathrm{K}^{+}$was recorded during post-monsoon 2014-15, while the maximum ( $\left.0.87 \mathrm{mg} \mathrm{L}^{-1}\right)$ during premonsoon 2014-15. These similar trends were also reported in water bodies of central India with lower concentration of $\mathrm{K}^{+}$during in post-monsoon season and this was attributed due to sedimentation and utilization [2]. The potassium values reported from Tighra reservoir with an average of $2.92 \pm 0.07 \mathrm{mg} \mathrm{L}^{-1}$ and from Harsi reservoir reported $\mathrm{K}^{+}$concentration ranged from 1.54 to $4.80 \mathrm{mg} \mathrm{L}^{-1}[12,17]$.

\section{CONCLUSION}

The Ambawade reservoir, showed the monthly and seasonal variations in the physico-chemical characteristic of water. The variations in physicochemical parameter showed that, the primary peak of nutrients was observed during premonsoon season followed by monsoon and postmonsoon season. The primary peak of nutrient might have been influenced by nutrient availability during pre-monsoon due to evaporation of water and bright sunlight, while the organic runoff from agriculture and nutrient coming along with the rainfall during monsoon played the major role in the nutrient concentration which may latter helps in the development of plankton availability in the reservoir. The availability of nutrient supports the good biota in the reservoir and is suitable for stocking of fish seed for development of culture based capture fishery.

\section{ACKNOWLEDGEMENT}

The authors wish to thanks the authorities of College of Fisheries, Shirgaon, Ratnagiri and Shramjivi Janta Sahayak Mandal, Mahad for providing me all the necessary facilities as well as for giving the needful support during the course of investigation.

\section{COMPETING INTERESTS}

Authors have declared that no competing interests exist.

\section{REFERENCES}

1. Gupte A, Shaikh N. Seasonal variations in physicochemical parameters and primary productivity of Shelar lake Bhiwandi, Thane, Maharashtra. Universal Journal of Environmental Research and Technology. 2013;3(4):523-530.

2. Kaushik S, Saksena DN. Physico-chemical limnology of certain water bodies of Central India. Freshwater ecosystems of India (Vijaykumar K, Ed.), Daya Publishing House, New Delhi, India; 1999.

3. Boyd CE. Water quality in warm water ponds. Auburn University, Agricultural Experiment Station, Alabama; 1981.

4. Anonymous, Indian Standards 3025 - 45: Methods of sampling and test (physical and chemical) for water and wastewater, Part 45: Sodium and potassium; 1993.

5. Khanna DR, Bhutiani R. Laboratory manual of water and wastewater analysis. Daya publication house, New Delhi; 2008.

6. Trivedi RK, Goel PK. Chemical and biological methods for water pollution status. Environmental Publication, Karad (India); 1986.

7. Namdeo AK, Shrivastava $P$, Sinha S. Seasonally varying limnology of a tropical irrigation reservoir: Barna Reservoir. Journal of Chemical, Biological and Physical Sciences. 2013;3(3):2309-2316. 
8. Mohammad MJ, Krishna PV, Lamma OA, Khan S. Analysis of water quality using limnological studies of Wyra reservoir, Khammam District, Telangana, India. International Journal of Current Microbiology and Applied Sciences. 2015;4(2):880-895.

9. Shinde SE, Pathan TS, Raut KS, More PR, Sonawane DL. Seasonal variations in physico-chemical characteristics of Harsool - Savangi dam, district Aurangabad, India. The Ecoscan. 2010;4(1):37-44.

10. Patil S, Patil SS, Sathe TV. Limnological status of Khanapur freshwater reservoir from Ajara tahsil, Kolhapur district (MS), India. International Journal of Science, Environment and Technology. 2013;2(6): 1163-1174.

11. Garg RK, Rao RJ, Saksena DN. Water quality and conservation management of Ramsagar reservoir, Datia, Madhya Pradesh. Journal of Environmental Biology. 2009;30(5):909-916.

12. Uchchariya DK. Study of nutrients and trophic status of Tighra reservoir, Gwalior (Madhya Pradesh), India. Journal of Natural Sciences Research. 2012;2(8):97110.

13. Kadam CP, Dandolia HS, Kaushik S, Saksena DN, Shrotriy VP. Trophic status of Pillowa reservoir of Morena, Madhya Pradesh, India. Journal of Chemical, Biological and Physical Sciences. 2014;4(4):3751-3761.

14. Sakhare VB, Joshi PK. Ecology of Palasnilegaon reservoir in Osmanabad district Maharastra. Journal of Aquatic Biology. 2002;18(2):17-22.

15. Lianthuamluaia, Landge AT, Purushothaman CS, Deshmukhe G, Ramteke KK. Assessment of seasonal variations of water quality parameters of
Savitri reservoir, Poladpur, Raigad district, Maharashtra. The Bioscan. 2013;8:13371342.

16. Singh S, Agrawal N. Study on water quality of Govindgarh lake of district Rewa (M.P.), India in reference to fisheries and bioremediation. Proceedings of Environmental Stress \& Its Remedies. 2014;26-35

17. Pawaiya N, Khushwah MKS, Sharma DK. Seasonal variation in water quality of Harsi reservoir Dabra, Gwalior district, Madhya Pradesh. Proceedings of Environmental Stress \& Its Remedies. 2014;1-25.

18. Mullar RM, Rajashekhar M, Vijaykumar K, Haliked NS. Seasonal variation in physicochemical parameters of Hirahalla reservoir, Koppal District Karnataka. International Journal of Systems Biology. 2010;2(2):1620.

19. Sugunan VV. Reservoir fisheries of India. FAO Fisheries Technical Paper. No. 345. Rome; 1995.

20. Sharma DK, Singh RP. Correlation between physico-chemical parameters and phytoplanktons of Tighra reservoir, Gwalior, Madhya Pradesh. International Journal of Science and Nature. 2013;4(1): 90-95.

21. Jhingran VG. Fish and fisheries of India, $3^{\text {rd }}$ edition. Hindustan Publishing Corporation (India), Delhi; 1991.

22. Venkatasubramani $\mathrm{R}$, Meenambal $\mathrm{T}$. Study of sub-surface water quality in Mattupalayam Taluk of Coimbatore district Tamil Nadu. Nature Environment. and Pollution. Technology. 2007;6:307-310.

23. Sawant R, Chavan N. Water quality status of Mahagaon reservoir from Gadhinglaj tahsil from Maharashtra. International Journal of Science, Environment and Technology. 2013;2:1196-1204.

(0) 2017 Lokhande et al.; This is an Open Access article distributed under the terms of the Creative Commons Attribution License (http://creativecommons.org/licenses/by/4.0), which permits unrestricted use, distribution, and reproduction in any medium, provided the original work is properly cited.

Peer-review history:

The peer review history for this paper can be accessed here: http://sciencedomain.org/review-history/19532 